EESTI NSV TEADUSTE AKADEEMIA TOIMETISED 1954. III kd., nr. 1 ИЗВЕСТИЯ АКАДЕМИИ НАУК ЭСТОНСКОИ ССР 1954. ТоМ III, № 1

\title{
JUURVILJADE RUUTPESITI KASVATAMINE JA SELLE MAJANDUSLIK EFEKTIIVSUS
}

\section{K. VAHENOMM}

Ruutpesiti kasvatamise meetod on vaheltharitavate kultuuride viljelemisel viimastel aastatel ulatuslikult levinud. Eriti on seda kasvatusviisi rakendatud kartuli ning silokultuuride, samuti ka köögiviljade kasvatamisel, kus ta on andnud silmapaistvaid tulemusi nii suuremate saakide saavutamise kui ka inimtööjõu kokkuhoiu osas. Nende kultuuride ruutpesiti kasvatamisest on vastavas kirjanduses avaldatud ka arvukaid uurimistulemusi ning tähelepanekuid kolhooside ja sovhooside tootmispraktikast.

Selle meetodi rakendamisest juurviljade kasvatamisel on aga avaldatud üsna vähe andmeid. Ometi on nende väärtuslikkude ja saagirikaste söögija söödakultuuride ulatuslikumat kasvatamist seni pidurdanud peamiselt just suur inimtööjõunõudlus. Nende kultuuride külvipindalade suurendamisel ja viljakuse tõstmisel, nagu seda eriti rõhutatakse Nõukogude Liidu Kommunistliku Partei Keskkomitee septembripleenumi otsustes, on seepärast otsustava tähtsusega nii hooldustööde kui ka sügiseste koristustööde igakülgne mehhaniseerimine. Küsimus juurviljade kasvatamise mehhaniseerimisest on otseselt seotud nende külvi- ja istutamisviisiga. Ruutpesiti kasvatamise meetod, mis võimaldab mehhaniseeritud vaheltharimist mitmes suunas ja samaaegselt vähendab töökulusid ka tõusmete harvendamisel ja sügisesel juurviljade koristamisel, on juurviljade kasvatamisel seepärast olulise tähtsusega.

Pioneeriks juurviljade ruutpesiti kasvatamise alal Eesti NSV-s on olnud Valga rajooni kolhoosi „Stalini Tee” lülivanem C. Kalm, kes juba kauemat aega on ruutpesiti kasvatanud mõningaid köögivilju ja söödajuurvilju. Võrdlemisi väikese tööjōuga on C. Kalm selle meetodi kasutamisel suutnud korras hoida kolhoosi "Stalini Tee" ulatuslikud köögi- ja söödajuurviljade seemnekasvatuslikud külvid ning ka ühiskarja söödabaasi täiendamiseks tehtud juurviljakülvid.

Akadeemia presidendi J. Eichfeldi soovitusel, kellele need külvid 1950. aastal ühel ringsõidul, umbrohust puhastena eriti silma paistsid, alustas Eesti NSV Teaduste Akadeemia Taimekasvatuse Instituudi köögiviljanduse laboratoorium 1951. aastal selle juurviljade külvi- ja istutusviisi lähemat uurimist. Korraldatud katsetes selgitati juurviljade ruutpesiti kasvatamist nii kultuuri esimesel kui ka teisel (s. o. seemnete kasvatamise) aastal, kusjuures lähemalt jälgiti taimede bioloogilist arenemist erineva suurusega pesades ning antud meetodi majanduslikku efektiivsust võrreldes juurviljade tavalise reaskasvatamisega.

Katseid korraldati Polli ja Kuusiku filiaalides laboratooriumi temaatilises plaanis ette nähtud põldkatsetena, samuti aga ka suurematel pindala- 
del Abja rajooni Karksi ja Tartu rajooni Lenini-nimelises kolhoosis. Kultuuri esimesel aastal uuriti kõnealuse meetodi rakendamist nii taimedest istutamise kui ka seemnete otse kohale külvamise puhul, kuna kultuuri teisel aastal selgitati seemneistikute rühmiti istutamise mitmesuguseid võimalusi.

Allpool esitame nendest töödest tähelepanekuid juurviljade ruutpesiti kasvatamisest kultuuri esimesel aastal.

Esimesel aastal võib juurvilju kasvatada kas seemne otsese külvamise teel alalisele kasvukohale või mõningaid juurvilju - nagu peet ja kaalikas - ka istikutest kasvatamise kaudu. Mõlemal juhul on seda võimalik teha ruutpesiti meetodil. Et istikutest kasvatamise puhul ei nõua ruutpesiti meetodi rakendamine nimetamisväärset lisakulu ka kevadiste tööde ajal, sest ajakulu mõttes on ükskõik, kas taimed istutatakse rühmiti või ritta, alustati tööd istikute ruutpesiti paigutamise võimaluste uurimisega.

1951. aastal oli katsetamisel söödapeet Eckend orf. Taimede ruutpesiti istutamiseks markeeriti põld $75 \times 75 \mathrm{~cm}$ piki- ja ristisuunas ning istutati 4 taime markeerimisjoonte ristumiskohtadele diagonaalselt $18-23 \mathrm{~cm}$ külgedega ruutudesse. Pesade kaugus üksteisest oli sel juhul mõlemas suunas $52-57 \mathrm{~cm}$. Niisugune istutusviis võimaldas vaheltharimist hobukultivaatoriga piki ja risti pōldu kuni 1. augustini, kokkı 3 korda.

Tavalisel ühes reas kasvatamisel oli ridade vahelaius $55 \mathrm{~cm}$ ja taimede vahekaugus reas $20 \mathrm{~cm}$. Kumbagi varianti kõblati peale 3 -kordse vaheltharimise veel 2 korda käsitsi, millega hoiti lapid umbrohust täiesti puhtad.

Kokkuvõtlikke andmeid selle katse tulemustest on esitatud tabelis 1 .

Tabel 1

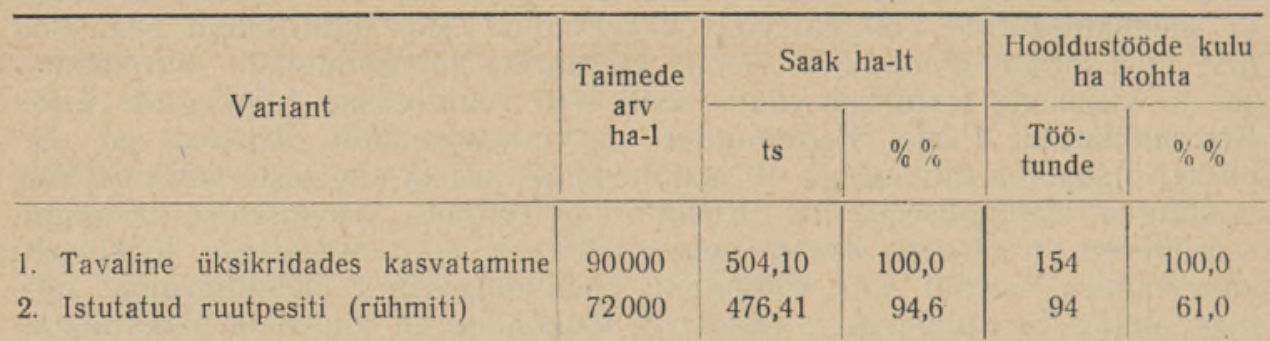

Nagu esitatud andmetest selgub, on korraldatud katses taimede rühmiti istutamisel saak olnud küll $5,4 \%$ väiksem üksikridades kasvatamisel, hooldustööde kulu seevastu on aga rühmiti istutamisel tunduvalt väiksem. moodustades ainult $61 \%$ istikute reaskasvatamise töökulust. Kokkuhoid hooldustööde kuludes on tingitud eeskätt sellest, et ridades kasvatamisel kulus umbrohu kõrvaldamiseks käsitsi kõplamisega märgatavalt rohkem aega kui rühmiti kasvatamisel, kus kolmekordsel mõlemasuunalisel hobukultivaatoriga vaheltharimisel jäi umbrohtudele kasvamisvõimalusi väga piiratud alal.

Miks rühmiti istutamisel saak väiksem oli, selgub, kui vaadelda taimede arvu hektaril. Taimede istutamisel ridadesse taimede eelmainitud vahekauguse ja ridade vahelaiuse juures mahtus hektarile 90000 taime, rühmiti istutamisel $75 \times 75 \mathrm{~cm}$ ruutude kasutamise korral aga ainult 72000 . Loomulikult pidi selle tõttu vähenema ka saak. Kui aga omavahel võrrelda taimede arvu vähenemist ja saagi langust, selgub, et $20 \%$ väiksem taimede arv hektaril on rühmiti kasvatamise korral põhjustanud ainult $5,4 \%$-lise saagilanguse. Järelikult on kahes suunas vaheltharimine loonud taimedele tunduvalt paremad kasvutingimused, mis taimede võrdse arvu juures võib anda olulise enamsaagi rühmiti istutamise kasuks. 
Jälgides taimede kasvu vegetatsiooni ajal ja vaheltharimise võimalusi, võis aga konstateerida, et hektarile võib paigutada tunduvalt rohkem taimi, kui seda oli tehtud käesolevas katses. 1952. aastal võrreldigi sama kultuuri rühmiti istutamist $70 \times 70$ ja $65 \times 65 \mathrm{~cm}$ vahekaugustega markeeritud põllul. Istikud istutati samuti nagu eelmisel korral markeerimisjoonte ristumiskohtadele mõlema diagonaali suunas, kuid nõnda, et ruutude küljed olid $15-20 \mathrm{~cm}$. Selgus, et $70 \times 70 \mathrm{~cm}$ suuruste ruutude juures on takistamatu vaheltharimine mõlemas suunas täiesti võimalik ning samuti on küllaldaselt ruumi ka taimede kasvuks; $65 \times 65 \mathrm{~cm}$ ruutude kasutamisel tuli aga vaheltharimisega olla võrdlemisi ettevaatlik.

Seega võib söödapeedi istikutest kasvatamisel normaalseks pidada $70 \times 70 \mathrm{~cm}$ suurusi ruutusid, mille nurkadesse on istutatud 4 istikut. Seejuures paigutatakse hektarile umbes sama arv taimi kui reas kasvatamisel, kus ridade vahe on $55 \mathrm{~cm}$ ja taimede vahekaugus reas $20-25 \mathrm{~cm}$.

Samal aastal korraldati vastav katse söödapeediga ka Abja rajooni Karksi kolhoosis. Selle katse tulemused on esitatud tabelis 2.

Tabel 2

\begin{tabular}{l|c|c|c|c}
\hline \multirow{2}{*}{ Kasvatamisviis } & \multicolumn{2}{|c|}{ Saak ha-lt } & \multicolumn{2}{c}{ Töökulu ha kohta } \\
\cline { 2 - 3 } & ts & $\% \%$ & päevades & $\% \%$ \\
\hline 1. Oherealine vagudel & 283 & 100,0 & 92,1 & 100,0 \\
2. Ruutpesiti (rühmiti) & 403 & 142,4 & 85,4 & 92,7
\end{tabular}

Saak selle, tootmistingimustes korraldatud katse puhul pole kummalgi variandil eriti suur, sest kasvatati väikesekasvulist sorti ja kõiki hooldustöid ei saadud teostada nõuetekohaselt ja õigeaegselt. Taimede rühmiti kasvatamine andis siin aga $42,4 \%$ enamsaaki ja seda väiksemate töökulude juures. Niisuguse suure saagivahe peamiseks põhjuseks oli asjaolu, et rühmiti istutamisel oli kolmekordse piki- ja ristisuunas vaheltharimise ja ühekordse kõplamisega võimalik hoida põld peaaegu puhtana umbrohust, kuna vagude sama arvu ühes suunas vaheltharimise ja vagude ühekordse, olgugi rohkem aega nõudnud pealtkõplamisega ei suudetud umbrohtu sel määral kõrvaldada, mispärast see osa põllust jäi võrdlemisi umbrohuseks ja saak seetôttu oluliselt väiksemaks.

Et söödapeedi rühmiti istutamine andis häid tulemusi, siis rajati 1952. aastal katsed ka juurviljade ruutpesiti kasvatamise võimaluste selgitamiseks seemnete otseselt avamaale külvamise korral. Katseid alustati söögipeedi sordiga $\mathrm{B}$ or doo. Et ruutpesiti külviks polnud kasutada vastavat masinat, siis külvati seeme käsitsi. Selleks markeeriti põld $60 \times 60 \mathrm{~cm}$ vahekaugustega mõlemas suunas ja seeme külvati markeerimisjoonte ristumiskohtadesse. Seemned kaeti kõplaga kergelt mulda peale tõmmates. Külvinorm oli $11 \mathrm{~kg}$ ha-le. Võrdluseks külvati külvimasinaga kaherealine ribaskülv $60 \times 25 \mathrm{~cm}$, kusjuures seemet kulus ha-le $21 \mathrm{~kg}$.

Vaheltharimisega alustati mõlema variandi puhul kohe pärast taimede tõusmist, teostades seda suve jooksul 4 korda sili ja kultivaatoriga, ruutpesiti külvil mõlemas suunas, ribaskülvil ainult piki laiemat reavahet. Viimase variandi kitsamaid reavahesid hariti kõplaga 4 korda. Ruutpesiti külvi harvendati üks kord, ribaskülvi kaks korda.

Kokkuvõtlikke andmeid katsest on esitatud tabelis 3 .

Saak on ruutpesiti külviviisi puhul ka selles katses jäänud $5,4 \%$ võrra väiksemaks kaherealise ribaskülvi saagist. See, kuigi väike, saagivahe on, samuti nagu seda võis märkida eespool, põhjustatud eeskätt ruutpesiti külvi tunduvalt väiksemast taimede arvust hektaril. Nimelt jäeti ruut- 
Tabel 3

\begin{tabular}{l|c|c|c|c|c}
\hline \multirow{2}{*}{ Variant } & \multicolumn{2}{|c|}{ Saak ha-lt } & $\begin{array}{c}\text { Sellest } \\
\text { văikesi } \\
(\% \%)\end{array}$ & $\begin{array}{c}\text { Ohe tonni peetide } \\
\text { tootmiseks töötunde } \\
\text { külvi-ja hooldustöödel }\end{array}$ & $\begin{array}{c}\text { Taimede } \\
\text { arv } \\
\text { ha-1 }\end{array}$ \\
\cline { 2 - 5 } & ts & $\% \%$ & & & 135000 \\
Ruutpesiti külv & 420,6 & 94,6 & 3,0 & 6 & 200000 \\
2-realine ribaskülv & 442,3 & 100,0 & 3,7 & 15 &
\end{tabular}

pesiti külvi harvendamisel pesadesse keskmiselt 4-5 peeti, s. o. $130000-140000$ taime hektarile. Kasvu jälgimisel selgus, et tegelikult võib taimi pesades olla märgatavalt rohkem. Seda tõestab ka tabelis märgitud väikeste peetide protsent, mis ruutpesiti külvil on isegi väiksem reas täpselt $8-10 \mathrm{~cm}$ vahekaugusele harvendatud kaherealise ribaskülvi vastavast protsendist.

Kui aga võrrelda kahe esitatud külviviisi tööjõunõudlust, siis selgub, et ruutpesiti külvil on ühe tonni peetide tootmiseks töötunde külvi- ja hooldustöödel kulunud k a k s ja pool korda vähem kui tavaliselt söögipeedile soovitatava kaherealise ribaskülvi korral.

Nii viimase kui ka eespool esitatud katse andmeist võib juurviljade ruutpesiti külviviisi kohta teha kaks põhilist järeldust: esiteks, et juurviljade ruutpesiti kasvatamine nõuab tunduvalt vähem tööjõudu, ja teiseks, et selle külviviisi saakide suurus on suurel määral sõltuv pesade suurusest, s. o. taimede arvust pesades. Mõlema küsimuse lähemaks selgitamiseks korraldati 1953. aastal täiendavad katsed, milledes eriti püüti selgitada pesadesse sobivat taimede arvu, mis, nagu märgitud, on toodangu suuruse kujunemisel olulise tähtsusega.

Taimede arv pinnaühikul on juurviljade kasvatamisel üldse võrdlemisi erinev. Nõnda võib mitmerealiste ribas- või viirgkülvide rakendamisel pinnaühikule paigutada väga palju taimi. On loomulik, et ruutpesiti külvi puhul ei saa pinnaühikul kasvatada niisama palju taimi kui reaskülvi puhul, sest môlemas suunas vaheltharimine võtab vaieldamatult rohkem ruumi. Ruutpesiti külvide saagid jäävad tihedate ribaskülvide saakidest veidi väiksemaks. Kui aga võrrelda reas- ja ruutpesiti külvide saake võrdse taimede arvu juures, siis on ruutpesiti külvide saak reaskülvide omast tunduvalt suurem. Seepärast on vajalik leida ja kasutada toodangu kvaliteedi seisukohalt maksimaalset taimede hulka pesades. Samuti on vaja määrata mehhaniseeritud vaheltharimiseks sobiv väikseim pesade vahekaugus. SeI viisil võib ka juurviljade ruutpesiti kasvatamisel paigutada pinnaühikule suurel hulgal taimi, mis toodangut tunduvalt suurendab.

Katsed riende küsimuste uurimiseks teostati 1953. aastal kõigi meie tähtsamate juurviljakultuuridega. Iga kultuuri puhul arvestati pesade suurust, määrati juurviljade kvaliteet erineva suurusega pesades, jälgiti taimede bioloogilist kujunemist, kasvu dünaamikat ja märgiti ka inimtöö kulu vastavatel tööperioodidel. Neist vaatlustest selgus, et juurviljade arv pesades võib üksikutel kultuuridel olla märgatavalt suurem, kui seda esialgu võis arvata. Eriti otstarbekohased olid suurema taimede arvuga pesad söögipeedil, millise kultuuri puhul teatavasti nõutakse keskmise suurusega juurvilju. Tabelis 4 on toodud pesade analüüsi andmed söögipeedi B o r d o o kohta.

Pesade suurus on tabelis märgitud koristamisel pesades olnud taimede arvu järgi, vaatamata sellele, kas neil juurvili oli moodustunud või mitte. Analüüs tehti $100 \mathrm{~m}^{2}$ suuruselt lapilt 0,25 -hektariselt ruutpesiti kasvatatud söögipeedi põllult. Külvatud oli käsitsi $60 \times 60 \mathrm{~cm}$ vahekaugustega mar- 


\begin{tabular}{|c|c|c|c|c|c|c|c|}
\hline \multirow{2}{*}{$\begin{array}{l}\text { Pesade suurus } \\
\text { (taimede arv } \\
\text { pesas) }\end{array}$} & \multicolumn{2}{|c|}{ Saak kg } & \multicolumn{4}{|c|}{ Sellest $(\% \%)$} & \multirow{2}{*}{$\begin{array}{l}\text { Arenemata } \\
\text { taimede keskmi- } \\
\text { ne arv pesas }\end{array}$} \\
\hline & pesast & ha-lt & $\begin{array}{l}\text { suuruselt üle } \\
\text { I sordi }\end{array}$ & I sorti & $\begin{array}{l}\text { suuruselt alla } \\
\text { I sorti }\end{array}$ & praaki & \\
\hline $\begin{array}{r}2 \\
3 \\
4 \\
5 \\
6 \\
7 \\
8 \\
9 \\
10 \\
11 \\
12 \\
13 \\
14\end{array}$ & $\begin{array}{l}1,0 \\
1,13 \\
1,58 \\
1,49 \\
1,79 \\
1,70 \\
1,83 \\
1,88 \\
1,81 \\
1,75 \\
2,26 \\
2,20 \\
1,69\end{array}$ & $\begin{array}{ll}27 & 777 \\
31 & 389 \\
43 & 888 \\
41 & 388 \\
49 & 722 \\
47 & 222 \\
50 & 861 \\
52 & 222 \\
50 & 277 \\
48 & 611 \\
62 & 777 \\
61 & 111 \\
46 & 944\end{array}$ & $\begin{array}{l}85,0 \\
47,1 \\
62,1 \\
35,8 \\
38,0 \\
39,4 \\
19,1 \\
20,1 \\
11,6 \\
16,4 \\
7,2 \\
9,1 \\
-\end{array}$ & $\begin{array}{l}15,0 \\
52,2 \\
37,4 \\
62,4 \\
59,2 \\
55,4 \\
75,1 \\
72,1 \\
83,2 \\
71,0 \\
85,5 \\
81,2 \\
86,8\end{array}$ & $\begin{array}{l}\overline{0,7} \\
0,7 \\
2,0 \\
3,5 \\
3,5 \\
5,0 \\
3,1 \\
8,8 \\
4,4 \\
6,1 \\
8,6\end{array}$ & $\begin{array}{l}\overline{-} \\
\overline{0,5} \\
1,1 \\
0,8 \\
1,7 \\
2,3 \\
2,8 \\
2,1 \\
3,8 \\
2,9 \\
3,6 \\
4,6\end{array}$ & $\begin{array}{l}\overline{0,5} \\
0,54 \\
0,55 \\
0,52 \\
1,0 \\
0,6 \\
1,0 \\
1,3 \\
1,3 \\
2,6 \\
2,83 \\
3,77\end{array}$ \\
\hline
\end{tabular}

keeritud põllule. Seega oli ühe pesa taimede toitepinna suuruseks $0,36 \mathrm{~m}^{2}$, millest tegelikult oli taimede all umbes $0,025 \mathrm{~m}^{2}$.

Esitatud andmete analüüs näitab, et saak hektarilt on taimede arvu suurenemisega kuni 12 taimeni pesas suurenenud peaaegu seaduspäraselt. Seejuures on ühtlasi tõusnud ka saagi kvaliteet. Nõnda on esimesse sorti kuuluvate peetide protsent taimede arvu suurenemisega samuti tõusnud, ulatudes 12 -taimelistes pesades $85,5 \%$-ni. Väiksemates pesades seevastu kõigub see protsent ainult $50-60$ pirides. Vastupidine on pilt suurte peetide osas. Siin on väiksemaarvulistes pesades suuruselt standardit ületavate juurviljade protsent tunduvalt suurem. Nõnda moodustavad 2-taimelistes pesades suured peedid kogusaagist $85 \%, 12$-taimelistes aga ainult $7,2 \%$. Väikeste peetide protsent on suuremates pesades muidugi suurem, kuid üldiselt on see võrdlemisi väike - 12 -taimelistes pesades näiteks ainult $4,4 \%$, missugusel määrat esineb väikesi juurvilju ka igas hästi harvendatud reaskülvis.

Bioloogilisest seisukohast lähtudes näib, et antud kasvutingimustes pole pesade tihedus põhjustanud liigisisest konkurentsi, vaid on ühtlustanud ja nivelleerinud üksikute pesaliikmete kasvu, mille tagajärjel suuremates pesades võis kujuneda ühtlane ja standardile vastav kõrge saak. See on tõendiks liigi piirides valitsevatest vastastikustest suhetest, mis on suunatud liigi olemasolu kindlustamisele, tema isendite arvu suurendamisele. Tõsi küll, pesades on esinenud ka sääraseid taimi, millel juurvili polnud moodustunud, mis nagu tõendaks nende allajäämist konkurentsis, kuid need taimed olid tõusnud hiljem idanema hakanud seemneist, mis vaheltharimisel kattusid mullaga ja leidsid alles siis idanemiseks võimalusi. Juurviljade suuruse kujunemisele on pesade tihedus muidugi mõju avaldanud, aga nagu tähelepanekud vegetatsiooni ajal näitasid, oleneb suurte juurviljade kujunemine suurel määral mulla viljakusest, õieti agrofoonist, s. o. pesades kasvatamisel rakendatud agrotehniliste võtete kompleksist, peamiselt sellest, kuivõrd pesaliikmetel oli kasutada vajalikke toitaineid ja vett. Jätkus toitaineid, kujunes suuri juurvilju nii väikese- kui ka suurearvulistes pesades. Oli aga toitainete kättesaadavus pesaliikmetele piiratud, nagu seda võib suurte pesade puhul oletada, nivelleerus juurviljade kasv, kusjuures kasv pidurdus suurematel juurviljadel, milledel oli individuaalseid eeldusi kasvada suuremaks. Teistel, loomuselt väiksemakasvulistel juurviljadel võis kasv aga koguni forsseeruda. Liigi tugevdamise ja kindlustamise seisukohalt on see arusaadav, sest taimele ja koos sellega ka liigile 
pole tähtis suurte juurviljade kujundamine; bioloogiliselt on need koguni ebakorrapärasused, millede suhteline seemnesaak vốrrelduna juurvilja suurusega on harilikult väike.

Ruumipuudus pesades on käesoleval korral vähem oluline, sest anatoomiliselt kujuneb juurvili söögipeedil peamiselt epikotülist ja hypokotülist, s. o. idulehtede pealmisest ja alumisest varrekese osast. Need asuvad aga valdavas enamuses maa peal. Seetõttu võivad pesa keskel asetsevad taimed juurvilja moodustada teiste pesaliikmete peal, kuna äärmised saavad ruumipuudusest üle sellega, et kasvavad tugevasti viltu, mōnel juhul koguni horisontaalselt. Pesaliikmete niisugust kasvu võib märgata mõlema meil rajoneeritud söögipeedi, nii Egiptuse kui ka Bordoo juures (joon. 1).

Praktiliselt võib seega söögipeeti ruutpesiti kasvatada vōrdlemisi suurtes pesades. Tabelis 4, nagu eespool märgitud, on pesade suurusrühmade

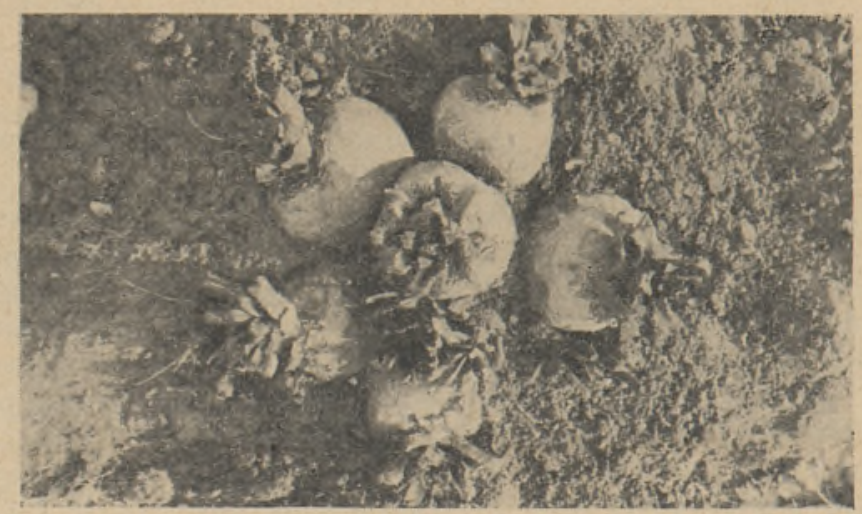

Joon. 1. Söögipeedi Bord oo 7-taimeline pesa.

määramisel arvesse võetud kõik koristamisel pesas esinenud taimed, vaatamata sellele, kas neil juurvili oli kujunenud või mitte. Viimased on märgitud lahtris ,,arenematud”. Et rõhuv enamus neist oli hakanud kasvama hiljem, peale vaheltharimisi ja suviseid vihmu, siis on nende osatähtsus pesa üldisel-kujunemisel väike. Pesa tegeliku suuruse määramisel tulevad need vastavast suurusrühmast lahutada. Nõnda on 12-taimelise pesa tegelikuks suuruseks $12-2,6$, keskmiselt 9,4 peeti. Sellele vastavalt tuleb söögipeedi ruutpesiti kasvatamisel sobivaimaks taimede arvuks pesas pidada 6-10. Niisuguse suurusega pesad on andnud kõrgeima ja kvaliteetseima saagi.

Porgandiga tehti vastav katse 250-ruutmeetrisel lapil, kus kasvatati laboratooriumi enda poolt selekteeritud sorti P-02. See on poolpikk, pisut kooniline, alt järsult ahenev sort, seega kujult pesades kasvatamiseks võrdlemisi sobiv. Põld oli markeeritud samuti $60 \times 60 \mathrm{~cm}$, kusjuures iga taime pesa all oli keskmiselt $0,04 \mathrm{~m}^{2}$. Katse tulemused on esitatud tabelis 6 .

Lahtris ,väikesi ja arenematuid" on märgitud pesaliikmed, mille suurus ei vastanud standardile ja mis seetõttu polnud turustamiskõlblikud. Need porgandid lihtsalt loendati ja arvutati, missuguse protsendi nad moodustavad pesas olnud porgandite a rvust. Pesa kaalus neid arvestatud ei ole.

Uksikuid suurusrühmi vaadeldes selgub, et porgandite arvu suurenemisel pesas suureneb ka saak. Nõnda on suurema saagi andnud 46- ja rohkemataimelised pesad. Samasugune oli pilt ka 1952. aastal korraldatud 
Tabel 6

\begin{tabular}{|c|c|c|c|c|c|c|c|}
\hline \multirow{3}{*}{$\begin{array}{c}\text { Pesade } \\
\text { suurus } \\
\text { (taimede arv) }\end{array}$} & \multicolumn{2}{|c|}{$\mathrm{S}$ a a $\mathrm{k}$} & \multicolumn{4}{|c|}{ Sellest kaalu jărgi protsentides } & \multirow{3}{*}{$\begin{array}{l}\text { Văikesi ja } \\
\text { arenematuid }\end{array}$} \\
\hline & \multirow[b]{2}{*}{$\begin{array}{c}\text { pesast } \\
\mathrm{kg}\end{array}$} & \multirow[b]{2}{*}{$\underset{\text { ts }}{\mathrm{ha}-\mathrm{lt}}$} & \multicolumn{3}{|c|}{ turustamiskõlblikke } & \multirow[b]{2}{*}{$\begin{array}{l}\text { lõhestunuid ja } \\
\text { deformeerunuid }\end{array}$} & \\
\hline & & & \begin{tabular}{|c|} 
üle 150 \\
$\mathrm{~g}$
\end{tabular} & $\begin{array}{c}80- \\
-150 \\
\mathrm{~g}\end{array}$ & $\left|\begin{array}{c}50-80 \\
\mathrm{~g}\end{array}\right|$ & & \\
\hline $\begin{array}{c}10-15 \\
16-20 \\
21-25 \\
26-30 \\
31-35 \\
36-40 \\
41-45 \\
46 \text { ja rohkem }\end{array}$ & $\begin{array}{l}1,90 \\
2,13 \\
2,53 \\
2,70 \\
2,77 \\
2,70 \\
3,04 \\
3,11\end{array}$ & $\begin{array}{l}527,77 \\
590,67 \\
702,78 \\
750,00 \\
769,44 \\
750,00 \\
844,44 \\
863,44\end{array}$ & $\begin{array}{l}43,2 \\
31,0 \\
28,4 \\
28,5 \\
23,5 \\
24,0 \\
25,0 \\
19,4\end{array}$ & $\begin{array}{l}50,0 \\
47,9 \\
54,2 \\
53,2 \\
58,5 \\
53,7 \\
55,6 \\
58,0\end{array}$ & $\begin{array}{r}2,6 \\
8,4 \\
7,9 \\
9,5 \\
10,8 \\
14,8 \\
11,6 \\
18,2\end{array}$ & $\begin{array}{r}4,2 \\
12,7 \\
9,5 \\
8,8 \\
7,2 \\
7,5 \\
7,8 \\
4,4\end{array}$ & $\begin{array}{l}18,5 \\
17,2 \\
18,8 \\
21,3 \\
22,6 \\
25,1 \\
24,5 \\
25,2\end{array}$ \\
\hline
\end{tabular}

katse puhul. See näitab, et porgandeid võib ruutpesiti kasvatada väga tihedates pesades. Suuremate juurviljade arv jääb seejuures küll väiksemaks, kuid keskmiste kvaliteetsete söögiporgandite suhteline hulk suureneb. Muidugi suureneb tihedamates pesades ka väikeste ja arenematute porgandite hulk, kuid mitte eriti palju. Nõnda on suuruselt mittestandardseid juurvilju suuremates pesades peaaegu ühtlaselt $24,5-25,2 \%$, mis 40 - 50 -st pesas asunud taimest moodustab arvuliselt $10-12$ tükki. Need ei lähe pealegi kaotsi, vaid annavad koos pealsetega väärtusliku sööda, mida kari meelsasti sööb.

Huvitav on seejuures märkida, et suuremates pesades, vaatamata tihedale seisule, pole deformeerunud kujuga ja lõhkisi juurvilju rohkem kui väiksema taimede arvuga pesades. Nende protsent on üldse kõikuv ja ei olene pesa suurusest.

Bioloogiliselt näib pesades kasvamine porgandile üldse sobivat. Liigisisest konkurentsi pole siin nagu eespoolkirjeldatud söögipeedi juureski märgata, mida näitab saagi pidev tõus taimede arvu suurenemisel pesades. Oieti peaks liigisisest konkurentsi käesoleval korral näitama tabeli viimane lahter, s. o. väikeste ja arenematute hulk, mis on küsimuse paremaks selgitamiseks esitatud arvulise protsendina. Teravama konkurentsi puhul peaks nende, s. o. väikeste ja arenematute või, teiste sõnadega, kasvus alla surutute protsent tiheduse suurenemisel pesades tunduvalt tõusma. Tegelikult tõuseb see aga väga vähe. Nõnda on neid kõige hõredamates pesades (10-15-taimeline suurusrühm) $18,5 \%$, kõige tihedamates (46 ja enamtaimeline suurusrühm) - $25,2 \%$, kusjuures kolmes viimases tihedamas suurusrühmas leidub neid peaaegu võrdselt: $25,1-25,2 \%$.

Muidugi peab taimedel olema juurviljade moodustamiseks vajalik ruum. Seepärast ei tule tihedaid pesasid käesoleva! korral mõista niisugustena, kus seeme on külvatud ühte punkti ja kus taimed on kasvanud muruna. Säärasest pesast kahtlemata ei saa 20-30 turukõlblikku juurvilja. Käesoleval korral oli pesade tegelik taimedealune pindala kuni vaheltharimiste lōppemiseni keskmiselt $13 \times 13 \mathrm{~cm}^{2}$.

Juurviljade lõplikuks kujunemiseks sellest pindalast muidugi ei jätkunud. Kui hiljem juurviljade suurenedes saabus ruumipuudus, said taimed sellest üle sel teel, et põllul, kus taimed kasvasid pesades tihedalt koos, surusid nad korduvate vaheltharimistega kobestatud ja pesade ümber kuhikutesse aetud mulla tugevasti laiali, mille tõttu taimedealune pindala oli sügisel juba pesa kohta keskmiselt $22 \times 22 \mathrm{~cm}^{2}$. Säärane pesa tuleb ka käsitsi koristamisel kergesti mullast välja. Korraldatud katsetes tulid vähe tugevama pingutusega tõmmates peaaegu kõik, ka 40 - 50 -taimelised pesad korraga mullast, mis koristamisel tunduvalt vähendas töökulu. 
Uldjoontes on pilt samasugune ka söödajuurviljade pesades kasvatamisel. Ka siin külvati seemned käsitsi $60 \times 60 \mathrm{~cm}$ vahekaugustega markeeritud põllule ja samuti nagu söögijuurviljade seemnedki mitte ühte punkti, vaid vähe suuremale pindalale - peete $10-15$ seemet, naereid väheldane näputäis.

Siinkohal tuleb aga märkida, et parem on külvata mitte ruutude nurkadesse, vaid nende keskele. See on eriti otstarbekohane siis, kui markeerimiseks kasutatakse traktori haakeriistu - kultivaator-muldajaid jt., millega tõmmatakse põllule piki- ja ristisuunas $10-12 \mathrm{~cm}$ sügavad vaod. Seejuures tekivad ruudud, mille ääred on vähe kõrgemad, keskkohad aga madalamad. Säärastesse lohkudesse on kergem külvata, see nõuab vähem tähelepanu ja ka seemne mullaga katmine on hõlpsam. Ja mis veel tähtsam vagusid mööda on võimalik vahelt harida juba enne taimede tõusmist, läbi viia nn. pime vaheltharimine, mis umbrohtunud põllul on suure tähtsusega. Märgatavate vagude olemasolu üldse kergendab vaheltharimist, eriti esimest, tehakse seda siis enne või pärast taimede tõusmist.

Kui markeerimiseks kasutatakse pealegi samu või sama haardelaiusega riistu, millega hiljem toimub taimede vaheltharimine, siis on markeerimisel tekkinud vagusid mööda vaheltharimine nii piki kui ka risti põldu märgatavalt hõlpsam ja taimedele ohutum.

Kuidas pesade tihedus söödajuurviljade puhul saagi suurust mõjustab, selle kohta on andmeid esitatud tabelis 7 .

Tabel 7

\begin{tabular}{l|c|c|c|c|c|c}
\hline Pesade suurus & \multicolumn{3}{|c|}{ Söödapeet } & \multicolumn{2}{|c}{ Söödanaeris } \\
\cline { 2 - 5 } & $\begin{array}{c}\text { pesast } \\
\mathrm{kg}\end{array}$ & ha-lt ts & $\begin{array}{c}\text { juurvilja } \\
\text { keskmine } \\
\text { kaal }\end{array}$ & $\begin{array}{c}\text { pesast } \\
\mathrm{kg}\end{array}$ & ha-lt ts & $\begin{array}{c}\text { juurvilja } \\
\text { keskmine } \\
\text { kaal }\end{array}$ \\
\hline 1-taimelised & 1,88 & 522,00 & 1,880 & 1,4 & 433,00 & 1,400 \\
2-taimelised & 2,93 & 815,28 & 1,442 & 2,07 & 575,00 & 1,035 \\
3-taimelised & 3,53 & 980,70 & 1,189 & 2,76 & 767,55 & 0,921 \\
4-taimelised & 3,84 & 1066,51 & 0,959 & 3,08 & 857,00 & 1,028 \\
5-taimelised & 3,94 & 1093,10 & 0,789 & 2,95 & 829,25 & 0,597 \\
6-taimelised & 3,83 & 1065,47 & 0,638 & 2,85 & 791,67 & 0,475 \\
7-taimelised & 4,15 & 1154,49 & 0,593 & 3,16 & 877,78 & 0,451 \\
8-taimelised & 4,31 & 1198,0 & 0,540 & 1,65 & 458,30 & 0,206 \\
9-taimelised & 3,82 & 1069,4 & 0,428 & 2,7 & 750,0 & 0,300 \\
10-taimelised & 3,94 & 1094,4 & 0,394 & 2,2 & 608,3 & 0,220
\end{tabular}

Kõrgeima saagi on söödapeedil andnud seitsme- ja kaheksataimelised pesad. Veel suuremates pesades on saak vähenenud ja juurviljade keskmine kaal tunduvalt langenud, mistōttu need end enam majanduslikult ei õigusta. Juurviljade keskmine kaal on näiteks kümnetaimelistes pesades ainult $0,394 \mathrm{~kg}$, mis söödajuurviljade jaoks on väike. Suuri, s. o. üle $1,5 \mathrm{~kg}$ juurvilju ei esinenud nendes pesades üldse. 7 -8-taimelistes pesades on juurviljade keskmine kaal aga veel küllalt kõrge: $0,59-0,54 \mathrm{~kg}$. Need on harilikult 6-7-sentimeetrise läbimõõduga juurviljad, mis nii säilitamisel kui ka söötmisel on täiesti vastuvōetavad. Suured, mitme kilogrammi raskused juurviljad on valdavas enamuses seest kobedad või tühjad, nende söödaväärtus on väike ja nad säilivad halvasti.

Söödanaeri puhul on pilt kirjum. Suurem saak on siin kujunenud 4- ja 7-taimelistes pesades. Suuremates pesades on see tugevasti kõikunud ja ka järsult langenud. Näib, et sellele kultuurile on suuremates (tihedamates) pesades kasvamine bioloogiliselt vähem vastuvõetav. Peediga võrreldes on naeri leherosett laiuvam ning tema lehed hoiduvad maa ligi, mis 
nõuab palju ruumi ja takistab valguse kasutamist. Ka kujuneb O s te $\mathrm{r}$ s u n d o mil suur osa juurviljast mullas ja selleks omakorda on tihedates pesades muidugi vähe ruumi.

Seemnete kiire idanemise tõttu on aga naeri ruutpesiti kasvatamine võrdlemisi otstarbekohane. Kiiresti tärkavad tõusmed märgistavad juba

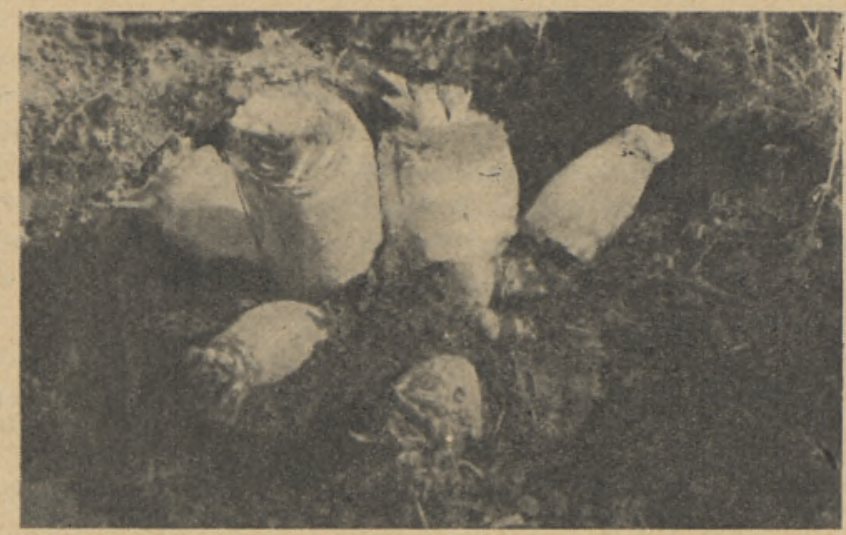

Joon. 2. Söödanaeri Ostersundom harvendamata pesa kõrgel agrofoonil.

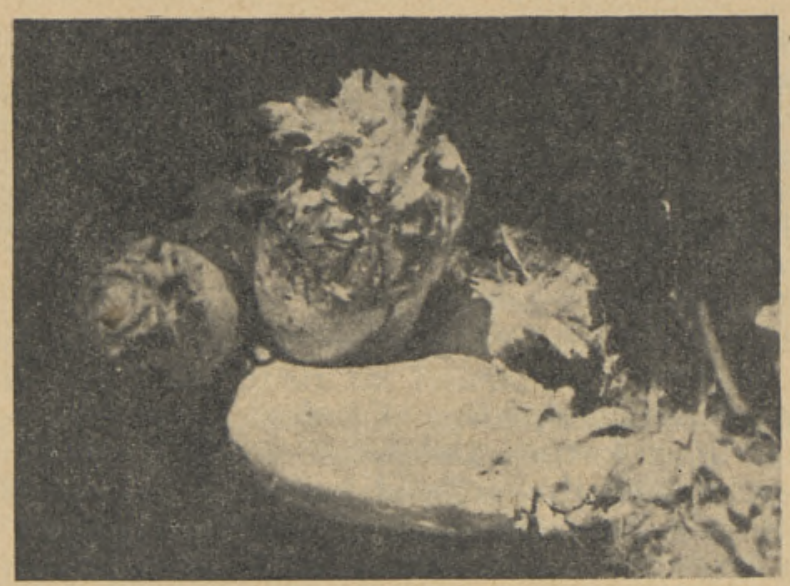

Joon. 3. Söödapeedi Ecken dorf 4-taimeline pesa.

4-5-ndal päeval pesade asukohad, mis võimaldab otsekohe asuda pesade vaheltharimisele. Ka on naeriste kasvatamisel peaaegu igal aastal vajalikku maakirpude ja naerimardika tõrjet pesades palju kergem teostada ja see nõuab ka märgatavalt vähem tõrjevahendeid kui naeriste kasvatamise puhul pidevates ridades.

Kokkuvõttes võib öelda, et nii söödanaerist kui ka söödapeeti saab edukalt kasvatada ruutpesiti. On selgunud, et ruutpesiti kasvatamisel on sobivaimate pesade suurusteks söödapeedil $4-8$ ja söödanaeril $4-7$ taime pesas. Niisugusel pesade suurusel saab ka põllu markeerimisel $70 \times 70 \mathrm{~cm}$, mis tunduvalt kergendab traktoritega vaheltharimist, hektarile paigutada samasuguse arvu taimi kui tavalisel reaskülvil (ca 100000 ), mis vajalikul agrofoonil kindlustab ka kõrge saagi. 
Põhilise majandusliku efekti annab juurviljade ruutpesiti kasvatamise meetod aga töökulude kokkuhoiu alal. Aastatel 1951-1953 tehtud vaatlused näitavad eranditult selle kasvatamisviisi väiksemat tööjõunõudlust harilikult kasutatavate reaskülvidega võrreldes ja seda nii taimedest istutamise kui ka seemne otse avamaale külvi korral. Suur tööjõunõudlus aga ongi olnud selleks peamiseks kitsaskohaks, mis seni on pidurdanud juurviljade ulatuslikumat kasvatamist.

Tabelis 8 on toodud andmeid tööjõunõudlusest nii reas- kui ka ruutpesiti kasvatamismeetodi puhul üksikute tööde järgi. Need andmed on muidugi ainult umbkaudsed, șest tööjõuvajadus on suurel määral olenev külvitihedusest, umbrohtumise astmest, umbrohtude õigeaegsest kõrvaldamisest ja reast muudest teguritest, mida kõike on raske täpselt arvestada. Esitatud andmed on saadud aja mõõtmisel, mis on kulunud samade tööde sooritamiseks kummagi külviviisi puhul aastatel 1951-1953.

Tabel 8

\begin{tabular}{|c|c|c|c|c|c|c|}
\hline \multirow{2}{*}{$\begin{array}{l}\text { Kultuuri } \\
\text { nimetus }\end{array}$} & \multicolumn{2}{|c|}{$\begin{array}{l}\text { Külvitööd, töötunde } \\
\text { ha-le }\end{array}$} & \multicolumn{2}{|c|}{$\begin{array}{l}\text { Hooldustööd, töö- } \\
\text { tunde ha-le }\end{array}$} & \multicolumn{2}{|c|}{$\begin{array}{l}\text { Ohe } t \text { koristamiseks } \\
\text { tunde }\end{array}$} \\
\hline & $\begin{array}{l}\text { ruutpesiti } \\
\text { (käsitsi) }\end{array}$ & $\begin{array}{l}\text { reas (hobukülvi- } \\
\text { masinaga) }\end{array}$ & ruutpesiti & reas & ruutpesiti & reas \\
\hline $\begin{array}{l}\text { Söödapeet } \\
\text { Söögipeet } \\
\text { Porgand }\end{array}$ & $\begin{array}{l}42 \\
42 \\
75\end{array}$ & $\begin{array}{l}10 \\
10 \\
18\end{array}$ & $\begin{array}{l}195 \\
206 \\
531\end{array}$ & $\begin{array}{r}345 \\
702 \\
1432\end{array}$ & $\begin{array}{l}5 \\
6 \\
7\end{array}$ & $\begin{array}{r}8 \\
9 \\
12\end{array}$ \\
\hline
\end{tabular}

Tööjõunõudlus on tabelis esitatud arvude järgi kõikidel kultuuridel üsna suur, kuid sellega on ka kõik nõutavad tööd teostatud, millega kindlustati head saagid, nagu seda võib näha eespool esitatud tabelitest. Söögipeedil ja porgandil on reaskülvide suuremat töökulu põhjustanud ka nende kultuuride kasvatamine nn. ribas- või viirgkülvidena (söögipeedil 2, porgandil 3 rida ribas), mis annab pinna ühikult suurema saagi, nõuab aga märgatavalt rohkem käsitsi tööd.

Nagu esitatud andmeist selgub, nõuab ruutpesiti külviviis kevadistel külvitöödel tunduvalt rohkem tööjõudu kui reaskülvid. See on arusaadav, sest vastavate masinate puudumisel on ruutpesiti külvid tehtud käsitsi, reaskülvid aga hobukülvimasinatega. Külvikulu moodustab aga suhteliselt väikese osa juurviljade kasvatamiskuludest. Pealegi toimub see ajal, kus tööjōud ei ole kuigi pingeliselt rakendatud. Seepärast õigustab end siinkohal seni, kuni pole kasutada vastavaid külvimasinaid, ka käsitsi külv, mis võimaldab kergemini valida sobivat külvimäära ja külvata suurema pindalaga pesasid. Vaheltharimisega kõrvaldatakse hiljem pesade keskustest kaugemale sattunud taimed ja jäetakse alles $15-20 \mathrm{~cm}$ külgedega ruudud, mis on vastava kultuuriga täielikult kaetud. Niisugusel $250-400 \mathrm{~cm}^{2}$ suurusel pindalal võib, nagu on eespool märgitud, suuremaid juurvilju kasvatada 4-8 tükki, väiksemaid aga mitu korda rohkem. Ohte punkti külvamisel niisugust taimede arvu pesas muidugi kasvatada ei saa. Sel juhul tuleb suurendada pesade arvu pinnaühikul, sest vastasel korral jääb toodang väikeseks.

Taimede edaspidistel hooldustöödel, mis moodustavad juurviljade kasvatamisel põhilise töökulu, on aga ruutpesiti külvi inimtööjõunõudlus mitmekordselt väiksem. See on eeskätt tirigitud kahesuunalise vaheltharimise võimalusest, mille tõttu käsitsi või kõplaga umbrohu tõrje vajadus jääb väga väikeseks. Tunduvalt kergem on ka pesade harvendamine, sest siin pole vajadust taimi harvendada üksteisest kindlale vahekaugusele, vaid harvendatakse ainult pesa, kui külv on osutunud ülearu tihedaks. Sobiva külvi- 
normi korral võib harvendamine ka üldse ära jääda. Enamikul juhtudest tuleb seda aga siiski teha. On soovitav seda teostada koos umbrohu kõrvaldamisega pesadest, mida nagunii vähemalt üks kord teha tuleb. Tihedaid pesasid on peale tõusmist otstarbekohane ka äestada kas võrk- või mõne muu kergema äkkega. Seda võib teha üsna julgesti, sest ruutpesiti külv talub äestamist märgatavalt paremini kui reaskülv. Käesolevas artiklis esitatud katsetes on igal kevadel peale tõusmist äestatud nii peeti, naerist kui porgandit. Muidugi tuleb arvestada seda, et äestatakse eeskätt harvendamise otstarbel. Hơredad külvid ei võimalda äestamist, kuigi seda umbrohu tõrjeks vaja oleks.

Ka pealtväetiste andmine pesadesse nõuab vähem aega, kusjuures väetis kasutatakse ära efektiivsemalt kui ridadesse külvi puhul. Kõik need võtted kokku vähendasid esitatud katsetes peaaegu kõikide juurviljade juures inimtöö vajadust taimede vegetatsiooniaegsetel hooldustöödel $2-3$ korda, mis mitmekordselt tasub ka käsitsikülvi suurema töökulu, eriti siis, kui koristamismasinaid pole veel käepärast.

Hõlpsam on ka ruutpesiti külvide koristamine. Pesades tihedalt üksteise vastu kasvades on juurviljad nõrgemini mullas, mispärast terve pesa tuleb tōmbamisel korraga mullast välja. Nagu eespool märgitud, tulid ühekordse tõmbamisega välja isegi $40-50$-taimelised üsna sügavasti mullas paiknevad porgandite pesad. Veel kergemini tulid lahti sööda- ja söögipeedi pesad, kus suurem osa vilju on vormunud pealpool mulda. Naeripesade koristamịne oli hapra ja laialivalguva leheroseti tõttu tülikam.

- Eespool esitatut kokku võttes võib märkida, et juurviljade ruutpesiti kasvatamine andis korraldatud katsetes silmapaistvaid tulemusi. Et on aga tegemist katse andmetega väiksematelt pindaladelt, siis on vaja saadud tulemusi igakülgselt kontrollida tootmises, kus selguvad nii ebatäpsused kui ka täiendavad võimalused selle meetodi mehhaniseerimiseks, eriti külvi osas, samuti ka pesade sobiva vahekauguse, külvimäära ja reas muudes agrotehnilistes küsimustes. Esitatu põhjal võib aga ütelda järgmist.

1. Bioloogiliselt osutub uurimisel olnud juurviljade ruutpesiti kasvatamine täiesti võimalikuks.

2. Ruutpesiti külvide saagid on suuresti olenevad taimede arvust pesades. Korraldatud katsetes andsid $60 \times 60 \mathrm{~cm}$ toitepinnal väärtuslikuma ja kõrgema saagi

porgandil -40 - ja rohkemataimelised pesad ( 863 ts ha-lt)
söögipeedil -6 - 10 -taimelised pesad (497-628 ts ha-lt)
söödapeedil $-4-8$-taimelised pesad (1067-1198 ts ha-lt)
söödanaeril $-4-7$-taimelised pesad $(857-878$ ts ha-lt).

3. Söödapeedi istikutest kasvatamisel osutus otstarbekohaseks markeerida põld $70 \times 70 \mathrm{~cm}$ ruutudeks ja saadud ruutude nurkadesse istutada 4 taime. Sellega paigutatakse pinnaühikule reaskasvatamisele lähedane taimede arv ja kindlustatakse ka mitte väiksem saak. Inimtöökulu rühmiti istutamisel oli $30-40 \%$ väiksem.

4. Söögipeedil ja porgandil oli pesades kasvanud juurviljade kvaliteet parem nende taimede üksikult kasvanud juurviljadest. Nõnda saadi söögipeedi $\mathrm{B}$ or d o o $10-12$-taimelistes pesades kasvanud juurviljadest I sorti kuuluvat saaki $85,5 \%$, üksiktaimedena kasvanud juurviljadest aga ainult $15 \%$. Porgandil P-02 oli hõredates pesades (10-20 porgandit) lōhestunud ja deformeerunud juurvilju $4,2-12,7 \%$, tihedates pesades (40 ja rohkem porgandit) aga $4,4-7,8 \%$.

5. Söödajuurviljadel (peet, turnips) kujunes suuremaid vilju tihedamates pesades vähem, kuid kogusaak oli suurim $7-8$-liikmelistes pesades. Juurviljade keskmine kaal neis pesades oli $0,45-0,59 \mathrm{~kg}$. 
6. Ruutpesiti külvil kulub seemet $30-40 \%$ vähem reaskülvi normist. Hinnaliste köögi- ja söödajuurviljade seemnete juures moodustab see olulise kokkuhoiu.

7. Kevadisel külviperioodil, kui vastavate masinate puudumisel seemendatakse käsitsi, nõuab ruutpesiti külv suuremat töökulu, kuid hooldus- ja koristustöödel, mis moodustavad juurviljade kasvatamisel põhilise töökulu, on inimtööjõu vajadus poolteist kuni kaks ja pool korda väiksem. Kokku moodustas ruutpesiti kasvatamisel inimtöökulu $30-60 \%$ juurviljade reaskasvatamise töökulust.

Eesti NSV Teaduste Akadeemia

Taimekasvatuse Instituut
Saabus toimetusse

2. II 1954

\section{КВАДРАТНО-ГНЕЗДОВОЙ СПОСОБ ВЫРАЩИВАНИЯ КОРНЕ- ПЛОДОВ И ЕГО ЭКОНОМИЧЕСКАЯ ЭФФЕКТИВНОСТЬ}

\section{К. Г. ВАХЕНЫMM}

\section{Резюме}

В период с 1951 по 1953 год в лаборатории овощеводства Института растениеводства Академии наук Эстонской ССР проведен ряд опытов по изучению возможности выращивания корнеплодов квадратно-гнездовым способом. В полевых опытах испытывался квадратно-гнездовой способ выращивания корнеплодов применением рассадной культуры и посевом семян. За неимением специальных машин, работы по уходу и уборке производились частично применением конных орудий механизации, частично вручную.

В проведенных опытах установлено, что кормовую свеклу при рассадной культуре можно высаживать гнездовым способом. Это создает возможность обработки междурядий в двух взаимно перпендикулярных направлениях. Для квадратно-гнездовой посадки поле маркеровалось в двух перекрестных направлениях с расстоянием $75 \times 75$ см. Рассада свекль была высажена в углах таких квадратов, по 4 растения в гнезде, с расстоянием между ними 18-23 см. При таком размещении растений затраты труда по возделыванию уменьшаются на $30-40 \%$ по сравнению с обычным однорядковым способом, урожай же не снижается.

При применении квадратно-гнездового посева семенами в поле, размаркерованном на квадраты с расстояниями $60 \times 60$ см (семена размещались на месте перекрещивания маркерных линий), урожай в значительной мере зависит от количества оставленных в гнезде растений. Установлено, что на хорошем агрофоне можно разместить в одном гнезде на площади питания в $0,36 \mathrm{~m}^{2}(60 \times 60 \mathrm{~cm})$ довольно большое количество растений. Так, наиболее высокий урожай был получен у столовой свеклы при 10 растениях в гнезде, у столовой моркови при 40 и более, у кормовой свеклы при 8 и у турнепса при 7 растениях.

Анализ товарных качеств урожая столовых сортов показал, что количество крупных, нетоварных корнеплодов с увеличением числа растений в гнезде уменьшается, средних же и мелких увеличивается, в силу чего рост корнеплодов в гнездах с большим количеством растений более равномерен. Особенно хорошо это подтвердилось в отношении столовой свеклы, у которой гнезда с большим количеством растений $(10-12)$ дали более высокий урожай хорошего качества корнеплодов. Так, например, у столовой свеклы сорта Бордо в гнездах с $3-5$ растениями корнепло- 
дов первого сорта было от 52,2 до $62,4 \%$ (по весу), в то время как в гнездах с 10-12 растениями корнеплодов первого сорта было от 83,2 до $85,5 \%$. Общий урожай с гектара в последнем случае достиг 627,8 ц.

Полученные данные о высоком урожае корнеплодов хороших товарных качеств в гнездах с большим количеством растений показывают, что густота растений в гнезде не обусловливает внутривидовой конкуренции, а наоборот, данные говорят о наличии таких внутривидовых взаимоотношений, которые направлены на укрепление существования вида, на увеличение количества индивидуумов одного вида.

B опытах с морковью это положение также подтвердилось. При применении таких же площадей питания $(60 \times 60 \mathrm{~cm})$ наивысший урожай получен также в гнездах с наибольшей густотой стояния растений. Так, например, в гнездах с 10-15 растениями урожай с гектара был 527,8 ц, в гнездах же с 46 и бо́льшим количеством растений урожай достиг 863,4 ц. Нестандартных корнеплодов при этом было в гнезде в первом случае $18,5 \%$ от числа растений в гнезде, во втором же случае $25,2 \%$.

При квадратно-гнездовом посеве кормовых корнеплодов наивысший урожай получен при площади питания одного гнезда $0,36 \mathrm{~m}^{2}$ : у кормовой свеклы при 8 растениях в гнезде (1198 ц с 1 га) и у турнепса при 7 растениях в гнезде ( 878 ц с 1 га). В гнездах с еще более густым стоянием растений наблюдалось резкое уменьшение среднего веса корнеплодов, поэтому большее загущение в гнездах при выращивании кормовых корнеплодов нецелесообразно.

Основные же преимущества квадратно-гнездового посева заключаются в том, что применение его позволяет значительно сократить затраты труда при возделывании корнеплодов.

В таблице 1 приведены сравнительные данные о затратах труда при квадратно-гнездовом и обычном, рядовом посеве корнеплодов.

Таблича 1

\begin{tabular}{|c|c|c|c|c|c|c|c|c|c|c|c|}
\hline & \multirow{3}{*}{\multicolumn{2}{|c|}{ Культура }} & & & & \multicolumn{4}{|c|}{ Затрачено часов на 1 га } & \multirow{2}{*}{\multicolumn{2}{|c|}{$\begin{array}{c}\text { Затрачено часов } \\
\text { на уборку одной } \\
\text { тонны корнепло- } \\
\text { дов }\end{array}$}} \\
\hline & & & & & & \multicolumn{2}{|c|}{ посева } & \multicolumn{2}{|c|}{$\begin{array}{c}\text { на уход за по- } \\
\text { севом }\end{array}$} & & \\
\hline & & & & & & $\begin{array}{c}\text { квадрат- } \\
\text { но-гнез- } \\
\text { дового } \\
\text { (ручного) }\end{array}$ & $\begin{array}{l}\text { рядо- } \\
\text { вого }\end{array}$ & $\begin{array}{c}\text { квадрат- } \\
\text { но-гнез- } \\
\text { довым }\end{array}$ & $\begin{array}{l}\text { рядо- } \\
\text { вым }\end{array}$ & $\begin{array}{l}\text { квадрат- } \\
\text { но-гнез- } \\
\text { дового } \\
\text { посева }\end{array}$ & $\begin{array}{c}\text { рядового } \\
\text { посева }\end{array}$ \\
\hline Кормовая & свекла & . & . & . & & 42 & 10 & 195 & 346 & 5 & 8 \\
\hline Столовая & свекла & . & . & . . & . & 42 & 10 & 206 & 702 & 6 & 9 \\
\hline Морковь & 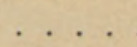 & , & . & . . & . & 75 & 18 & 531 & 1432 & 7 & 12 \\
\hline
\end{tabular}

Так как квадратно-гнездовой посев в опытах был произведен вручную, то затраты труда на посев превышают таковые при рядовом способе посева. Но затраты труда на посев при выращивании корнеплодов вообще незначительны по сравненню со всеми затратами по возделыванию культуры. Основные же затраты составляют работы по уходу и уборочные работы. В проведенных опытах затраты на уход и уборку в несколько раз меньше при квадратно-гнездовом способе посева по сравнению с затратами в случае рядового посева.

При выращивании кормовой свеклы из рассады целесообразно произвести маркеровку поля на квадраты $70 \times 70$ см и рассаду высадить в местах перекрещивания маркерных линий, по 4 растения в гнезде. При таком способе выращивания можно разместить на гектаре такое же количество 
растений, как и при рядовом посеве, что создает предпосылки к получению также и не меньшего урожая. Затраты труда при гнездовом способе посадки снижаются на $30-40 \%$.

При квадратно-гнездовом способе пेосева расход семян на 1 га уменьшается на $30-40 \%$ по сравнению с рядовым посевом. При возделывании культур, семена которых пока еще являются дефицитными, это дает ощутимую экономию семян, а также и денежных средств.

Институт растениеводства Академии наук Әстонской ССР
Поступила в редакцию 2 II 1954 